\title{
The usefulness of extended input-output tables incorporating firm heterogeneity
}

\author{
Satoru Hagino ${ }^{1}$ and Jiyoung Kim ${ }^{2^{*}}$
}

\author{
${ }^{*}$ Correspondence: \\ jiyoung@okayama-u.ac.jp \\ ${ }^{2}$ Graduate School \\ of Humanities and Social \\ Sciences, Okayama University, \\ 3-1-1 Tsushima-naka, Kita-ku, \\ Okayama 700-8530, Japan \\ Full list of author information \\ is available at the end of the \\ article
}

\begin{abstract}
This study examines the usefulness of an extended input-output table (EIOT) incorporating the heterogeneity of Japanese firms based on differences in ratios of imported intermediate goods to total output. Using an EIOT, the vertical specialization indicator of Japan was calculated, which corresponds to the foreign value added included in exports. In this process, differences in intermediate input ratios were measured examining different types of firms using firm-level microdata from the Basic Survey of Japanese Business Structure and Activities. The results indicate that distinguishing between exporting and non-exporting firms is relevant for assembly industries such as electronics and automobiles, as widely discussed in the literature. In contrast, for primary materials industries, such as paper, chemical, and metal industries, other distinctions appear to be more relevant. For example, for the chemical industry, wherein firms tend to have large, integrated manufacturing plants, the differences in intermediate import ratios are largest when distinguishing large firms from small and medium firms. For paper and metal industries, which rely on foreign raw materials, the difference is largest when distinguishing between firms with and without foreign affiliates. By incorporating such heterogeneity, the vertical specification indicator increases by $70 \%$; thus, the EIOT captures the foreign value added more comprehensively.
\end{abstract}

Keywords: Extended input-output table, Trade in value added, Incorporating firm heterogeneity, Vertical specialization

JEL classification: D57, F1

\section{Introduction}

In recent years, international conferences on national accounts have proposed extending input-output tables (IOTs) and supply and use tables (SUTs) to incorporate firm heterogeneity, along with active discussions on potential approaches for doing so (OECD 2014a, b, 2018). The Organisation for Economic Co-operation and Development (OECD) encourages the extension of IOTs or SUTs to improve the accuracy of its Trade in Value Added (TiVA) indicators by reflecting differences in the ratio of imported to total intermediate goods across heterogeneous firms in an industry.

For the calculation of TiVA, it is important to estimate the amount of imported intermediate goods as accurately as possible, as this is essential for calculating foreign value added. In the OECD's expert group on extended input-output tables (EIOTs) established author(s) and the source, provide a link to the Creative Commons licence, and indicate if changes were made. The images or other third party material in this article are included in the article's Creative Commons licence, unless indicated otherwise in a credit line to the material. If material is not included in the article's Creative Commons licence and your intended use is not permitted by statutory regulation or exceeds the permitted use, you will need to obtain permission directly from the copyright holder. To view a copy of this licence, visit http:// creativecommons.org/licenses/by/4.0/. 
in 2014, experts from various countries have discussed which elements of firm heterogeneity should be incorporated in EIOTs (Johnson and Noguera 2012; Ito et al. 2017). Thus far, the OECD has proposed assessing heterogeneity between exporters and non-exporters, domestically and foreign-owned, and large and small firms, in addition to firms with and without foreign subsidiaries (OECD 2015), as presented in Table 1.

In this context, this study considers the kind of firm heterogeneity that should be incorporated in Japan's EIOT. The research then examines the usefulness of such extension by estimating the vertical specialization (VS) indicator of Japan, which corresponds to TiVA's foreign value added included in Japan's exports.

The remainder of this paper is organized into three sections. Section 2 introduces methods, Subsection 3.1 discusses heterogeneity between exporters and non-exporters, and Subsection 3.2 that between large and small firms. Next, Subsection 3.3 focuses on domestically and foreign-owned firms, and Subsection 3.4 that firms with and without foreign subsidiaries. Subsection 3.5 describes the challenges of compiling Japan's EIOT, after determining an element of firm heterogeneity that produces the largest gap of imported intermediate ratio for each industry. In Subsection 3.6, Japan's VS indicators are calculated to examine the usefulness of the constructed EIOT. Section 4 concludes.

\section{Methods}

Using firm-level data from the Basic Survey of Japanese Business Structure and Activities (BSBSA) conducted by Japan's Ministry of Economy, Trade and Industry (METI), Hagino (2017) found the ratio of imported intermediates to output to be about $10 \%$ higher for exporters than non-exporters. To calculate the ratio, the author defined exporters as firms with non-zero exports. In contrast, studies for other countries often define exporters as firms that export at least $10 \%$ of their total sales. This research applied a different approach from Hagino's (2017), identifying exporters in terms of their export ratio (i.e., export/sales) in 10 percentage point increments, calculating the differences in intermediate import ratios between exporters and non-exporters.

The weight of distinctions between large and small firms and between exporters and non-exporters is assessed to determine differences in intermediate import ratios, using the firm-level data of the BSBSA. Two different methods are used to distinguish small and large firms. The first follows the Small and Medium-Sized Enterprise Act, which defines large firms as those with paid-in capital of more than 300 million yen. The second follows the Financial Statement Statistics of Corporations by Industry (FSSCI) of the Ministry of Finance, which defines large firms as those with paid-in capital of 1 billion yen or more.

The usefulness in distinguishing between foreign- and domestically owned firms in Japan is then examined, as in many developing and emerging economies, as well as highly internationalized developed economies, foreign-owned firms have a significant role in international trade.

The share of exports and imports accounted for by Japanese firms with foreign subsidiaries is also investigated. These shares for Japan are calculated from the BSBSA in comparison to corresponding shares for the U.K. and France from the OECD Trade by Enterprise Characteristics (TEC) database. Since the BSBSA does not cover very small firms, such firms are not included in this calculation; however, since very small firms 


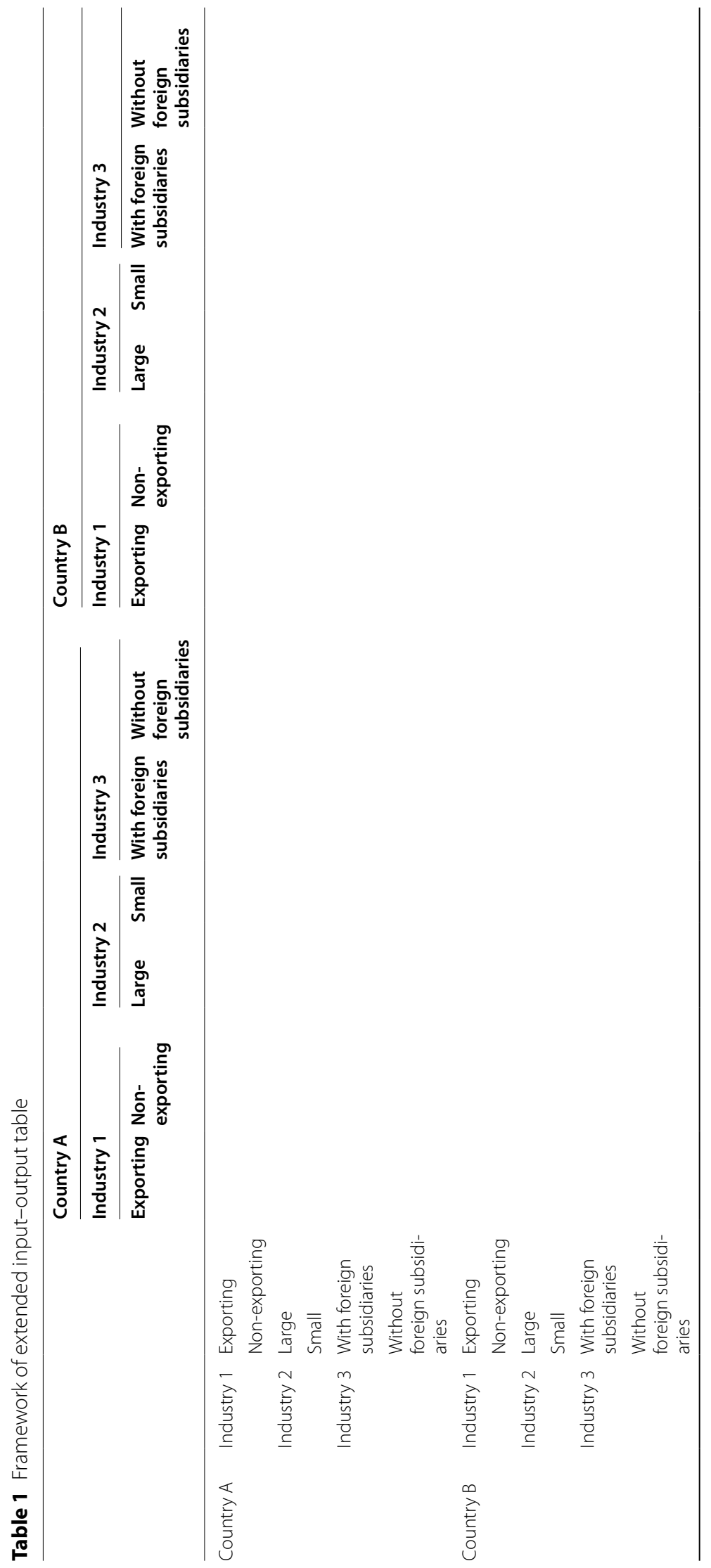




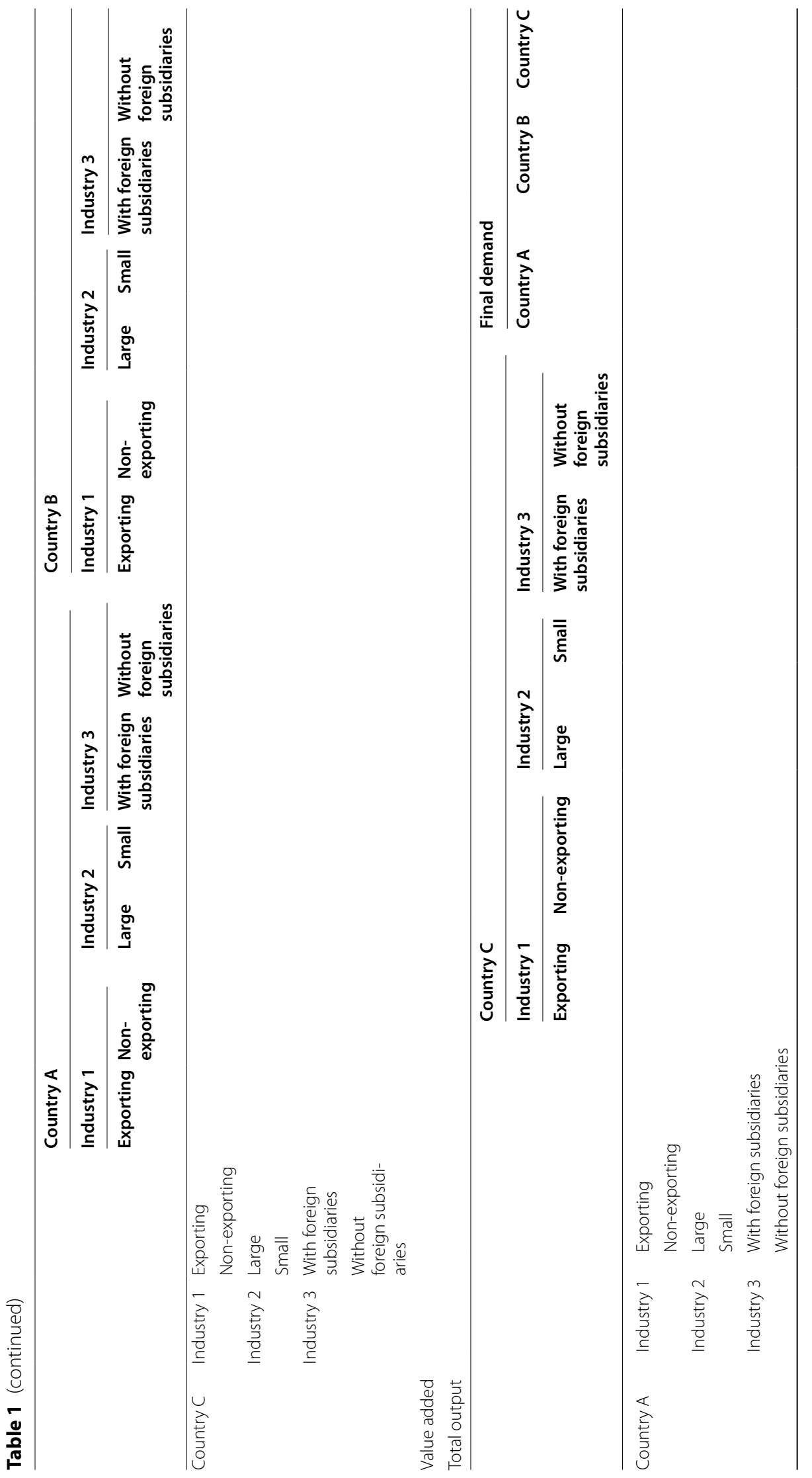




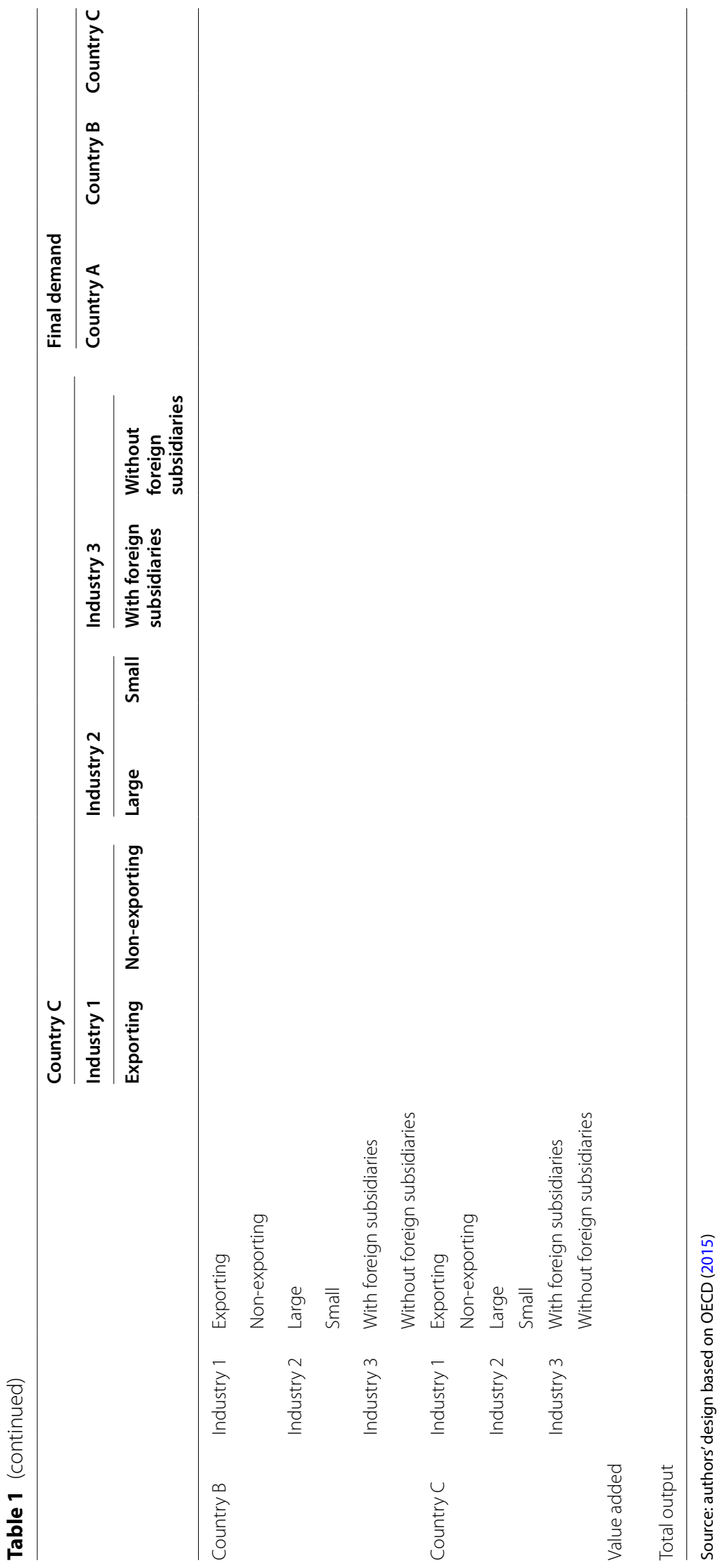


are generally unlikely to have foreign subsidiaries, this is not considered to materially affect the results. The U.S. Bureau of Economic Analysis developed an EIOT incorporating heterogeneity between firms with and without foreign subsidiaries, since many U.S. firms with foreign subsidiaries import intermediate goods from subsidiaries and such firms have an important role in international trade in general.

Based on above analyses, the EIOT developed for this research incorporates aspects of firm heterogeneity. As for the details of the compilation procedure, Japan's IO table, which we will refer to as the Benchmark IO Table, is compiled every 5 years in joint work involving ten government ministries coordinated by the Ministry of Internal Affairs and Communications. The Benchmark IO Table is non-competitive and separates the import table from the domestic table. It is based on producer prices, which include subsidies and taxes, such as consumption taxes.

A domestic table is produced by deducting the import table from the transaction table of the Benchmark IO Table and converting 108 product/activity classifications into 18 industry classifications for consistency with the TiVA classification (Table 2). This research focuses on the extension of intermediate input and demand using elements of firm heterogeneity to quantify the effectiveness of the extension; thus, final demand and value added are not separated.

Extending the Benchmark IO Table to incorporate firm heterogeneity requires separating the total output based on the type of firm heterogeneity considered for each industry. To do so, firm-level data from the BSBSA are used and calculate the weights, for which output shares are used. An extended import table is then constructed by incorporating the differences in intermediate import ratios.

Finally, the usefulness of the EIOT is examined by comparing VS indicators based on the EIOT with that of the non-extended Benchmark IOT. For this purpose, VS coefficients are calculated by multiplying the import coefficient matrix using the Leontief inverse matrix. The coefficients for each industry are then aggregated, referring to the aggregated figure as each industry's total VS coefficient. Industries' total VS is then calculated by multiplying the industry total VS coefficient by the number of exports. After aggregating each industry's VS amount, the VS indicator is calculated by dividing the aggregate VS amount by total exports. Finally, two different VS indicators are calculated based on the extended and non-extended IOTs.

The roots of the development of TiVA indicators can be traced back to the estimation of VS indicators (Hummels et al. 2001), which are calculated as the ratio of imported intermediate goods included in exports and are estimated using OECD IOTs. The VS indicator corresponds to foreign value added included in exports in the TiVA.

VS indicators can be estimated using one country's IOT. Defining $\mathrm{VSI}_{\mathrm{d}}$ as the direct imports deriving from exports, $X$ as the $n \times 1$ vector of exports of each industry, $X_{t}$ as a scalar of total exports of a country, $A^{m}$ as the $n \times n$ imported input coefficient matrix, $U$ as a $1 \times n$ vector of $1 \mathrm{~s}$ used for aggregating industries, and $\mathrm{n}$ as the number of industries, $\mathrm{VSI}_{\mathrm{d}}$ is given by:

$$
\mathrm{VSI}_{\mathrm{d}}=U \times A^{m} \times X \times X_{t}^{-1} .
$$

However, imports may indirectly derive from exports. For example, automobile manufacturers may import chassis to export cars, or may alternatively purchase chassis from 


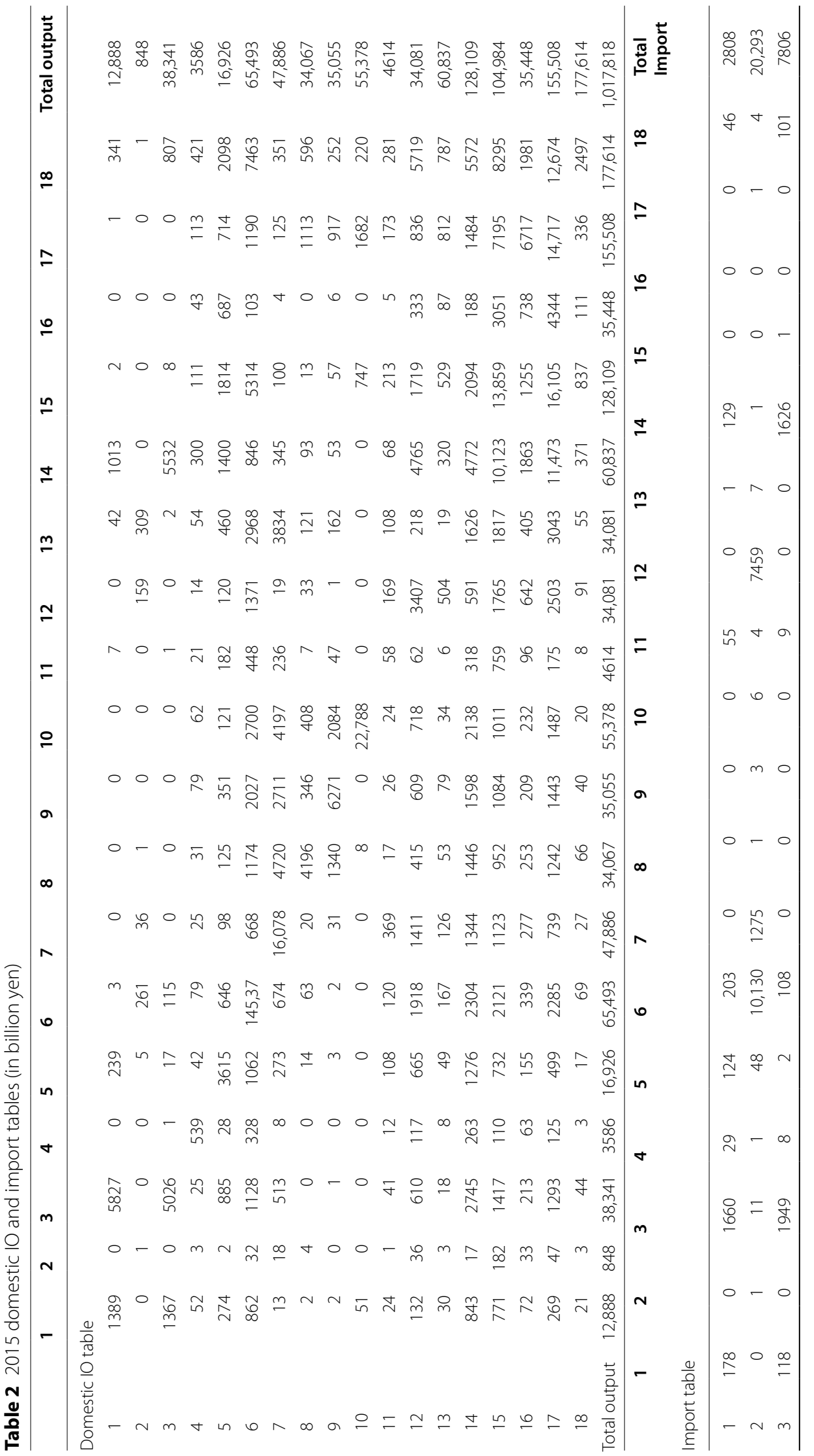




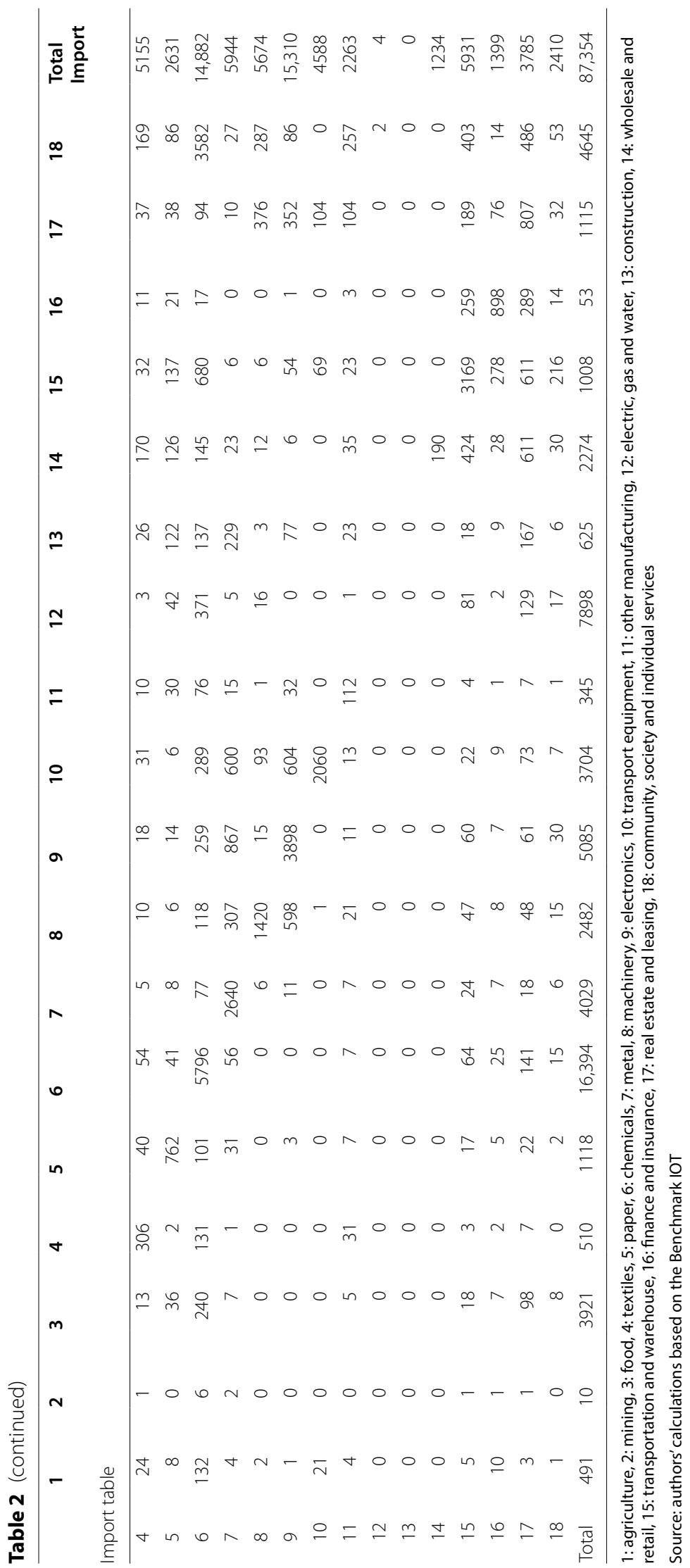


domestic manufacturers, who may import intermediate goods for chassis. Therefore, VS indicators should cover all imports deriving from exports, including imports through increases in domestic demand spurred by exports. Domestic demand deriving from exports can be calculated using the Leontief inverse matrix. Defining $A^{d}$ as the $n \times n$ input coefficient of domestic transactions matrix and $\left(I-A^{d}\right)^{-1}$ as the Leontief inverse matrix, VSI, which covers both direct and indirect imports from exports, is given by:

$$
\mathrm{VSI}=U \times A^{m} \times\left(I-A^{d}\right)^{-1} \times X \times X_{t}^{-1} .
$$

\section{Results and discussion}

\subsection{Heterogeneity between exporting and non-exporting firms}

The results of calculating the differences in intermediate import ratios between exporters and non-exporters are presented in Table 3.

The results indicate that, in the processing and assembly industries, the more a firm exports, the more it tends to import. In the electronic and optical equipment industry, the difference in the intermediate import ratio between exporters and non-exporters in 2011 was largest when focusing on exporters with an export ratio of 90\%, while in 2015, it was largest for those with an export ratio of $50 \%$. In the transport equipment industry, the difference in both years is largest for exporters with an export ratio of $100 \%$. In the machinery equipment industry, the difference in the intermediate import ratio between exporters and non-exporters remains relatively stable as the export ratio increases. In contrast, no clear pattern between the export ratio and the difference between exporters and non-exporters can be observed in primary materials industries. For the metals industry, the difference is largest for an export ratio of 10\%, both in 2011 and 2015. For the wood and paper products industry (hereafter, paper industry), the difference becomes larger as the export ratio increases. Conversely, for the textile industry, the difference is largest at an export ratio of 20\% in 2011 and 10\% in 2015 and then declines as the ratio increases. For the chemical industry, the difference is largest at an export ratio of $10 \%$ and then declines, even becoming negative, as the export ratio increases. These results indicate that other aspects of firm heterogeneity may be more crucial for identifying differences in the intermediate imports ratio.

The volume of transactions must be considered to determine the most appropriate export ratio to distinguish exporters from non-exporters. For example, in the transport equipment industry, a small number of export-intensive firms import, so the difference is largest for an export ratio of $100 \%$. To take the volume of transactions into consideration and identify the magnitude of exports to the imported intermediate ratios, the gap was multiplied by the volume of total inputs to calculate indices (Fig. 1). In this figure, "> 0-100\%", " $\geq 10-100 \%$ ", ..., " $\geq 90-100 \%$ ", 100\% means the ranges of export intensities (export sales ratios). We calculated the differences of import intermediate ratios between exporters and non-exporters that belong to the certain range of export intensities, by subtracting non-exporters ratios from exporters ratios. The magnitude of " $>0-100 \%$ " is defined to equal 100 as reference index. (However, " $>0-100 \%$ " in 2015 of wood and paper products industry is defined as -100 since it has a negative value.) Figure 1 demonstrates that the calculation for the export/sales ratio of " $>0-100 \%$ " for all 


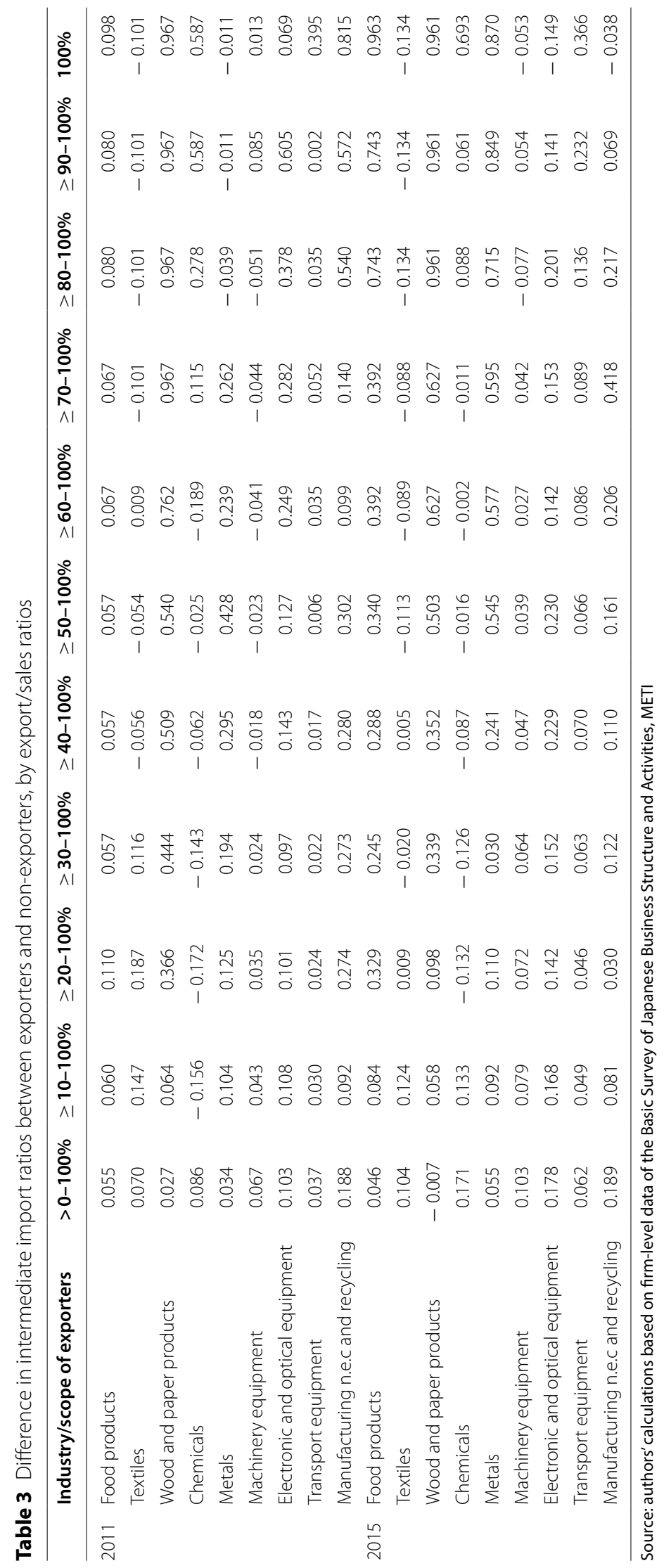




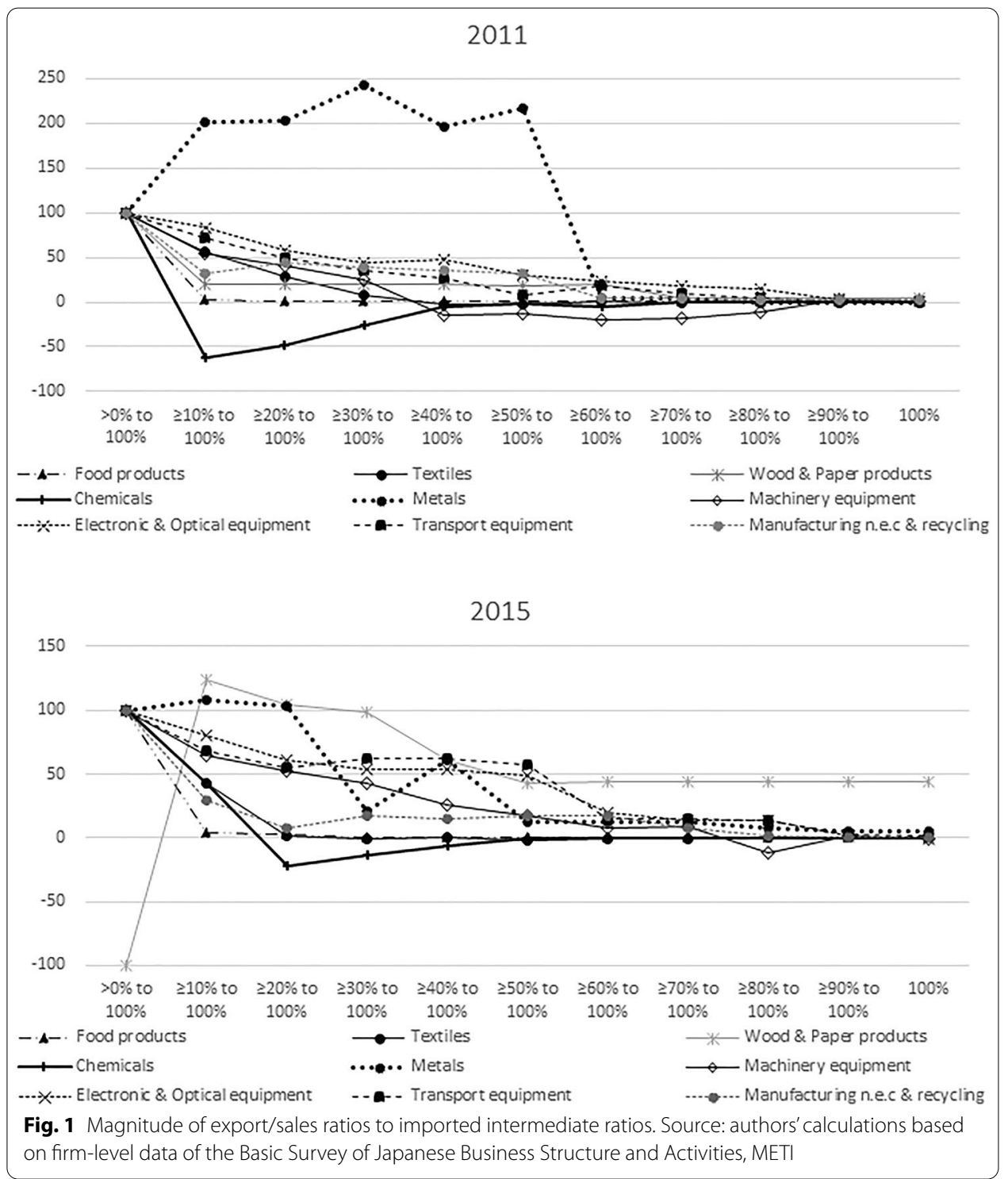

exporters produces the largest magnitude to the gap indices in all industries, the exception being the wood and paper products with the highest magnitude at " $\geq 10-100 \%$ " in 2015 (124.31), the metal industry with the largest magnitude at " $\geq 30-100 \%$ " in 2011 (243.06) and at " $\geq 10-100 \% "$ in 2015 (108.22). Given than such exceptions are not numerous, we regard that all exporters should be covered in distinguishing exporters from non-exporters.

\subsection{Heterogeneity between small and large firms}

Figures 2 and 3 present the differences in the intermediate import ratio between small and large firms by industry, with Fig. 2 showing the results based on the first definition and Fig. 3 those based on the second definition, comparing the differences between exporters and non-exporters (where exporters are defined as firms with non-zero exports). In the processing and assembly industries, the differences in intermediate 


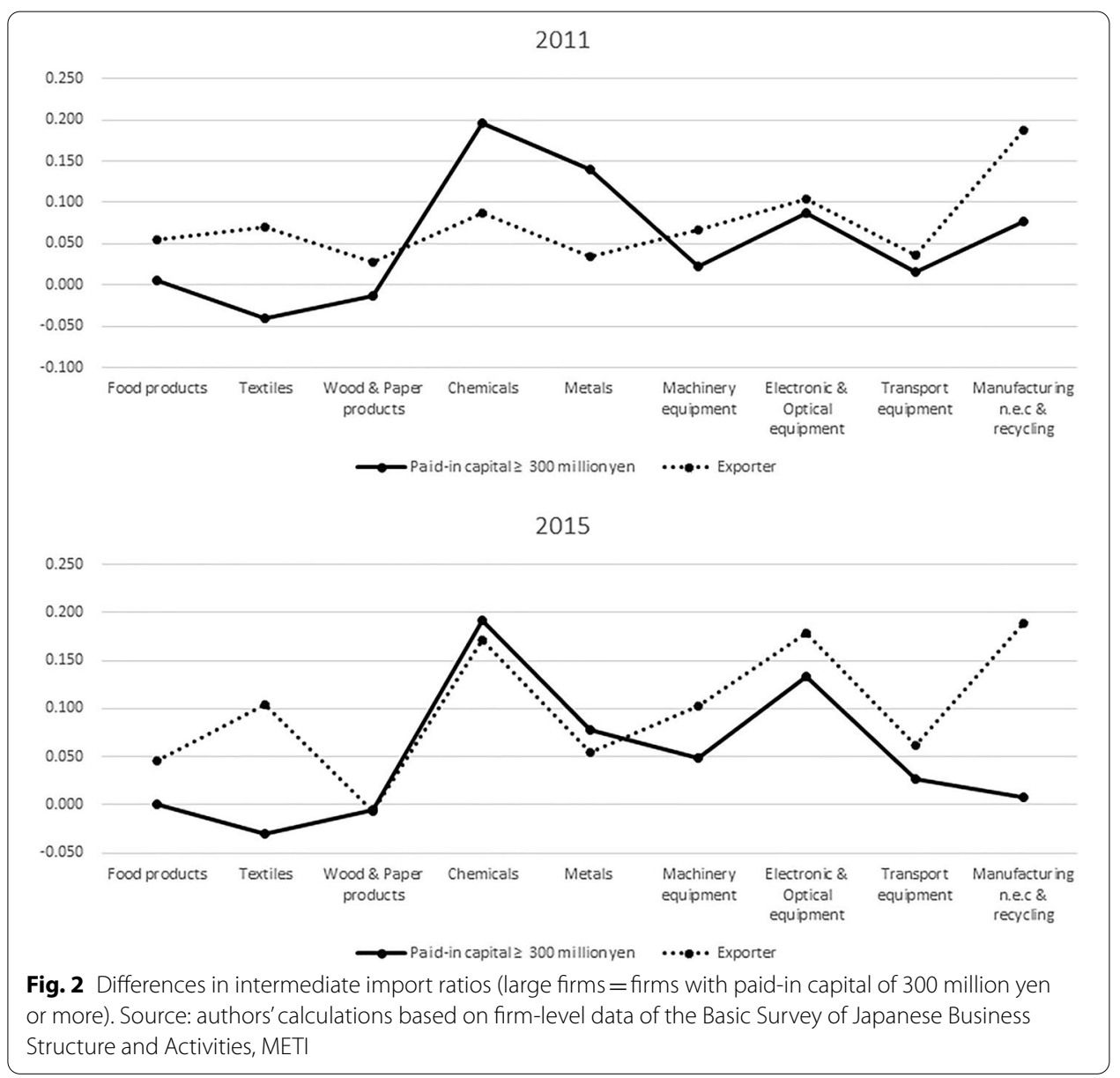

import ratios between exporters and non-exporters are found to be larger than those between small and large firms. Interestingly, for the electronic and optical equipment industry, the gap is larger when using the definition of the Small and Medium-Sized Enterprises Act (Fig. 2), which uses a lower capital threshold for large firms, than when using the definition of the FSSCI (Fig. 3), which uses a higher threshold. This indicates that there are a lot of medium-sized firms in the electronic and optical equipment industry between the two thresholds that engage in export.

The pattern for primary material industries differs considerably. For the chemical and metal industries, the differences in intermediate import ratios between small and large firms are larger than those between exporters and non-exporters. For the paper industry, the difference in 2015 between small and large firms was about the same as that between exporters and non-exporters. This indicates that heterogeneity regarding aspects other than exports may have a role for these industries. Interestingly, for the chemical industry, the difference is larger when using the definition of the FSSCI than when using the definition of the Small and Medium-Sized Enterprise Act. As discussed by Hagino (2017), this indicates that a small number of very large chemical firms operating integrated production systems, such as petroleum complexes, use large amounts of imported intermediates and materials. 


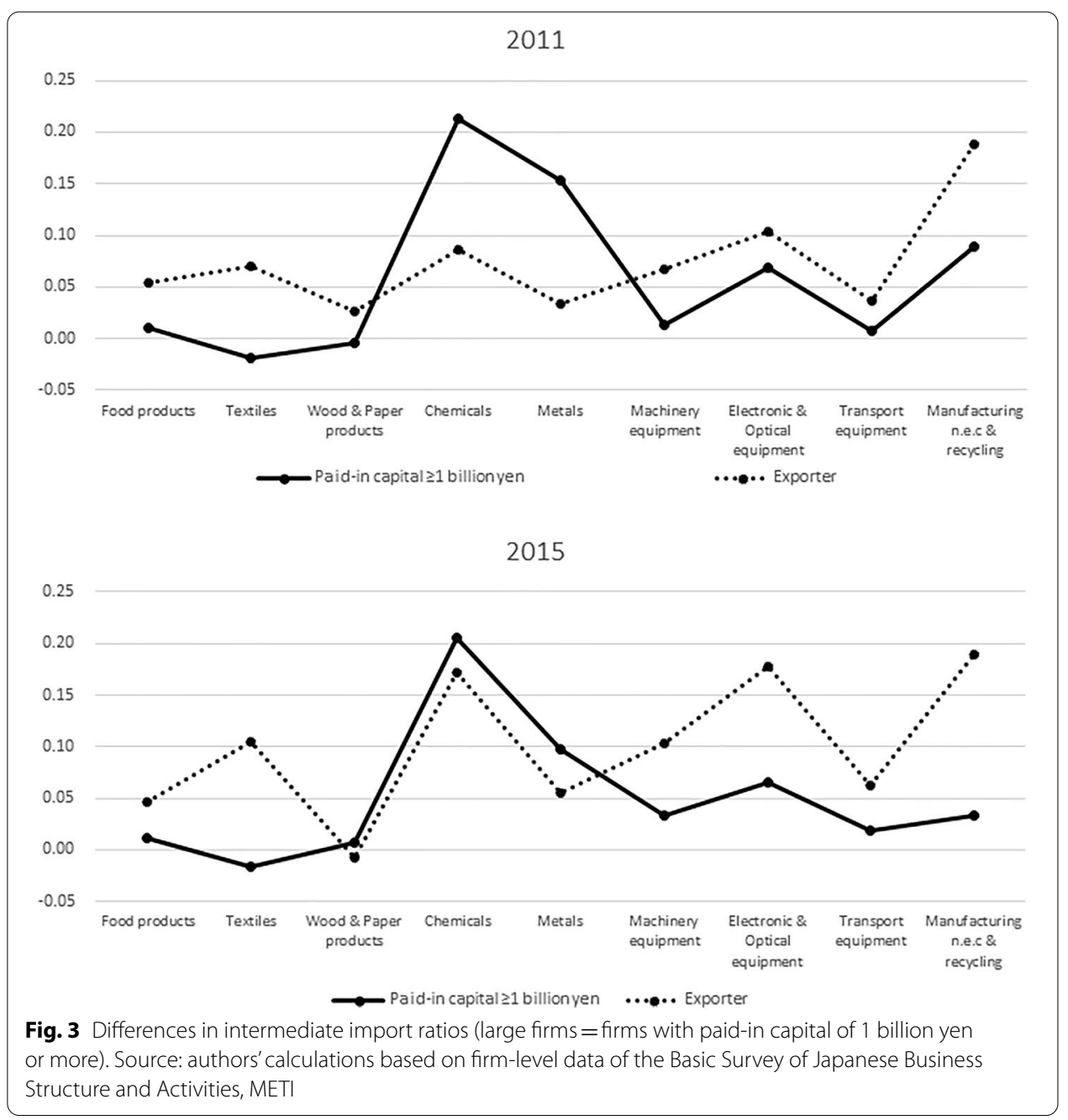

Table 4 examines the differences in the chemical and metal industries in more detail. For this purpose, the chemical industry is subdivided into petrochemical and non-petrochemical industries, and the latter is further subdivided into chemical, rubber, and ceramic products industries. Similarly, the metal industry is subdivided into the pig iron, forged products, nonferrous products, nonferrous processing, and other metal industries.

In the chemical industry, the difference is larger in the petrochemical industry than the non-petrochemical industry. Large petrochemical firms are equipped with capitalintensive integrated manufacturing complexes, and the use of imported intermediates and materials increases with the size of such firms, resulting in the large difference. Within the non-petrochemical industry, the differences in rubber and ceramic products industries are small but positive, while in the chemical products industry the difference is even negative. As highlighted by Hagino (2017), a likely reason for the negative difference in the chemical industry is that production in the industry tends to be divided into multiple stages, so that importers provide processed products to domestic firms and exporters process domestically produced products. 
Table 4 Differences in intermediate import ratios in the chemical and metal industries

\begin{tabular}{lccccc}
\hline Industry & $\mathbf{2 0 1 1}$ & & $\mathbf{2 0 1 5}$ & \\
\cline { 2 - 3 } $\begin{array}{l}\text { Paid-in } \\
\text { capital } \geq \mathbf{1} \\
\text { billion yen }\end{array}$ & $\begin{array}{l}\text { Paid-in } \\
\text { capital } \geq \mathbf{3 0 0} \\
\text { million yen }\end{array}$ & & $\begin{array}{l}\text { Paid-in } \\
\text { capital } \geq \mathbf{1} \\
\text { billion yen }\end{array}$ & $\begin{array}{l}\text { Paid-in } \\
\text { capital } \geq \mathbf{3 0 0} \\
\text { million yen }\end{array}$ \\
\hline Chemicals & 0.214 & 0.196 & & 0.206 & 0.191 \\
Petrochemical products & 0.335 & 0.314 & & 0.397 & 0.344 \\
Nonpetrochemical products & 0.058 & 0.048 & & 0.023 & 0.024 \\
Chemical products & 0.031 & 0.032 & & -0.027 & -0.029 \\
Rubber products & 0.126 & 0.084 & & 0.088 & 0.072 \\
Ceramic products & 0.044 & 0.038 & & 0.062 & 0.054 \\
Metal & 0.153 & 0.141 & & 0.098 & 0.078 \\
Pig iron & 0.269 & 0.26 & & 0.19 & 0.188 \\
Forged products & -0.012 & -0.013 & & -0.006 & -0.004 \\
Nonferrous products & 0.044 & 0.061 & & 0.048 & 0.018 \\
Nonferrous processing & 0.004 & 0.006 & & -0.009 & -0.05 \\
Other metal & -0.01 & -0.012 & & 0.003 & -0.006 \\
\hline
\end{tabular}

Source: authors' calculations based on firm-level data of the Basic Survey of Japanese Business Structure and Activities, METI

In the metal industry, the difference is larger in pig iron and nonferrous products industries than in the other sub-industries. Large iron and nonferrous products firms are equipped with capital-intensive integrated manufacturing complexes, and the use of imported intermediates and materials increases with the size of such firms, resulting in the large difference. The differences in the other metal industries (forged products, nonferrous processing, and other metal industries) are positive but small or negative. The reason, once again, seems to be that production in these sub-industries tends to be divided into multiple stages.

\subsection{Heterogeneity between domestic and foreign firms}

Figures 4 and 5 demonstrate that foreign-owned firms do not play a pivotal role in international trade in Japan, and that this distinction is less relevant than in other countries. Figure 4 compares the export and import shares accounted for by domestic and foreign firms in Japan and major European economies, while Fig. 5 shows the share of domestic and foreign firms in the total number of exporting and importing firms. The data for European countries are from the OECD's Trade by Enterprise Characteristics (TEC) database, which provides trade data (exports and imports) categorized by firms' characteristics, including ownership structure. For Japan, corresponding figures are estimated using firm-level data from the BSBSA. Although the BSBSA does not cover very small firms with less than 50 employees and 30 million yen of paid-in capital, omitting such small firms is unlikely to skew the results in a meaningful way.

Starting with Fig. 4, the results demonstrate that the share of exports and imports in Japan accounted for by foreign firms is much smaller than in European countries, especially in the case of exports, at around 5\%, it is almost negligible. A similar pattern is revealed in Fig. 5, which shows that the shares of foreign firms in the total number of exporting and importing firms in Japan are less than 3\%. These findings suggest that, in 


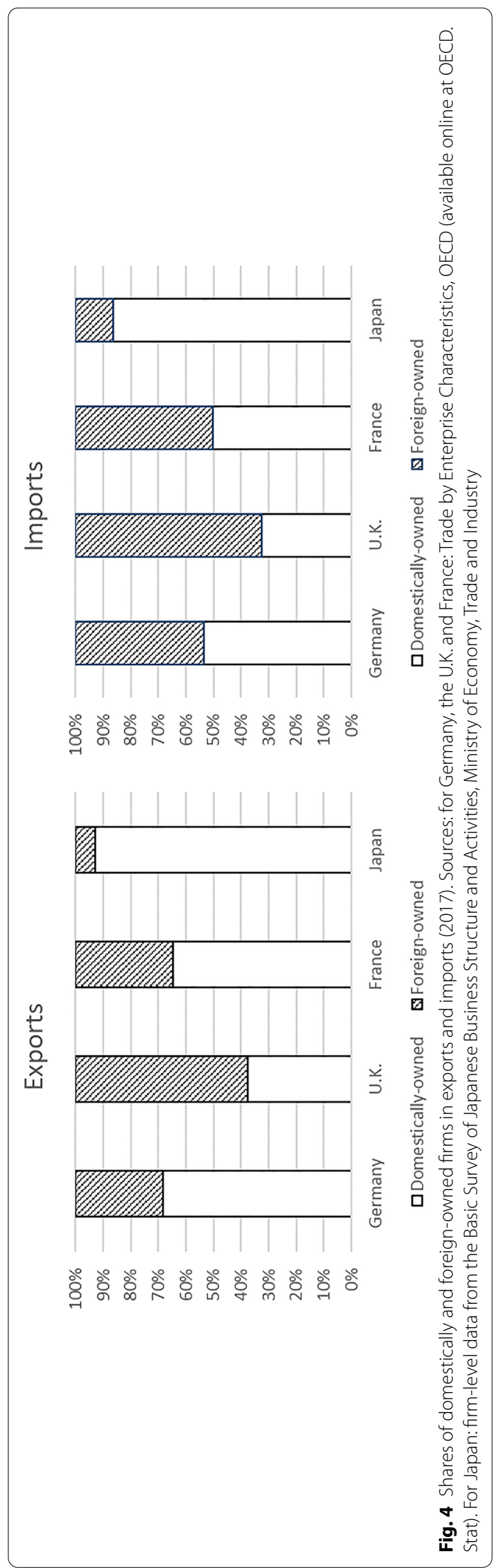




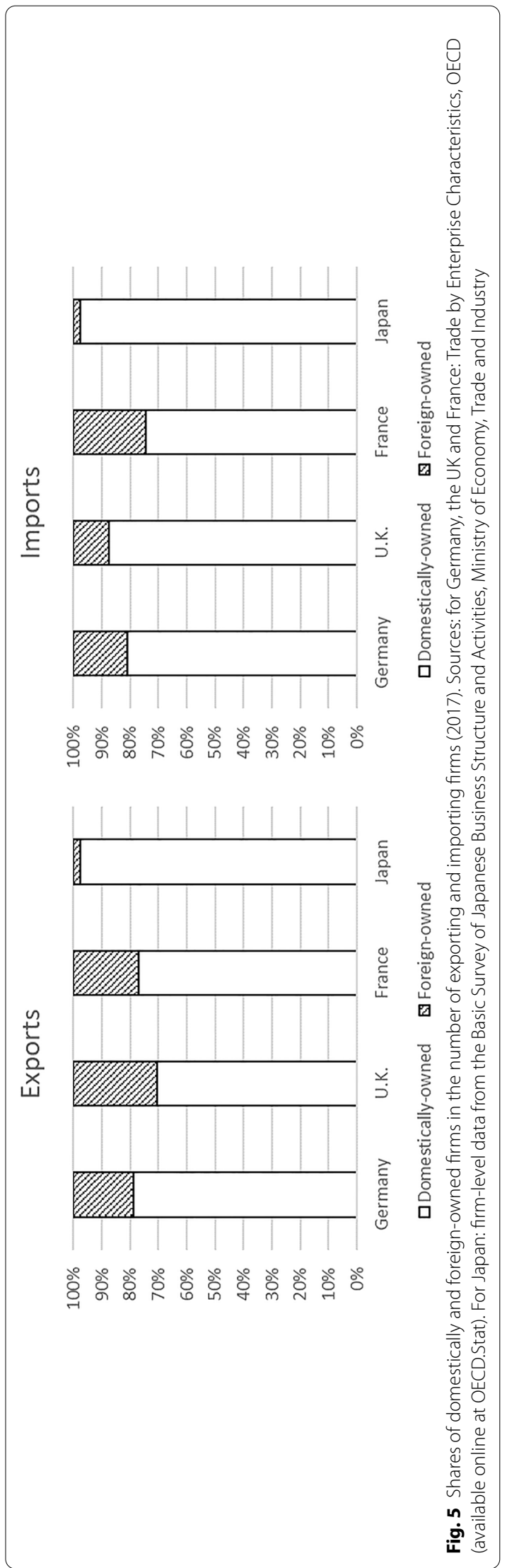


the case of Japan, distinguishing between domestically and foreign-owned firms is not a high priority when examining heterogeneity in intermediate imports.

\subsection{Heterogeneity between firms with and without foreign subsidiaries}

Figure 6 indicates that firms with foreign subsidiaries in Japan account for more than 95\% of all exports and imports, which is considerably higher than in France and the UK.

Therefore, differences in the intermediate import ratio between firms with and without foreign subsidiaries are calculated. The results are presented in Fig. 7 and reveal that the difference between firms in the metal industry with and without foreign subsidiaries is larger than those between exporters and non-exporters as well as those between small and large firms. This suggests that metal corporations, which need to import materials, have established subsidiaries for the exploration and mining of raw materials abroad. Thus, distinguishing between firms with and without foreign subsidiaries in the EIOT for the metal industry appears to be appropriate.

Furthermore, in the textile industry and the paper industry, the differences between firms with and without foreign subsidiaries are as large as those between exporters and non-exporters. Wood and paper products firms, which must import wood products, have established foreign subsidiaries to grow and harvest wood abroad. Similarly, many textile firms have established subsidiaries abroad, especially for sewing processes, to take advantage of lower labor costs in developing countries and import intermediates to Japan. Since the reliance on foreign subsidiaries by firms in these industries is likely to grow in the future, distinguishing between firms with and without foreign subsidiaries in the EIOT also seems appropriate for the wood and paper products and textile industries.

\subsection{Compiling Japan's EIOT}

The analyses in subsections (3.1-3.4) regarding the types of heterogeneity to incorporate in the Japanese EIOT have several implications. For processing and assembly industries, such as machinery, electronics, transport equipment, food, and textile industries, heterogeneity between exporters and non-exporters should be incorporated. For the chemical industry, heterogeneity between small and large firms should be incorporated, and for paper and metal industries, heterogeneity between firms with and without foreign subsidiaries should be incorporated.

As for the textile industry, the difference in intermediate import ratios between firms with and without foreign subsidiaries is as large as that between exporting and nonexporting firms; however, the share of exports accounted for by firms with foreign subsidiaries is quite small (Table 5). As for the heterogeneity between small and large firms, the intermediate import ratio of small firms is larger than that of large firms, so incorporating such heterogeneity is not consistent with theoretical assumptions; therefore, the most appropriate approach appears to be the incorporation of heterogeneity between exporting and non-exporting firms.

An extended domestic table was constructed by applying the weights to the total output of each manufacturing industry (Table 4) in the domestic table. Total output was separated into the output of exporters and non-exporters for the food, textile, machinery, electronics, transport equipment, and other manufacturing industries; of small and large firms for the chemical industry; and of firms with and without foreign subsidiaries 


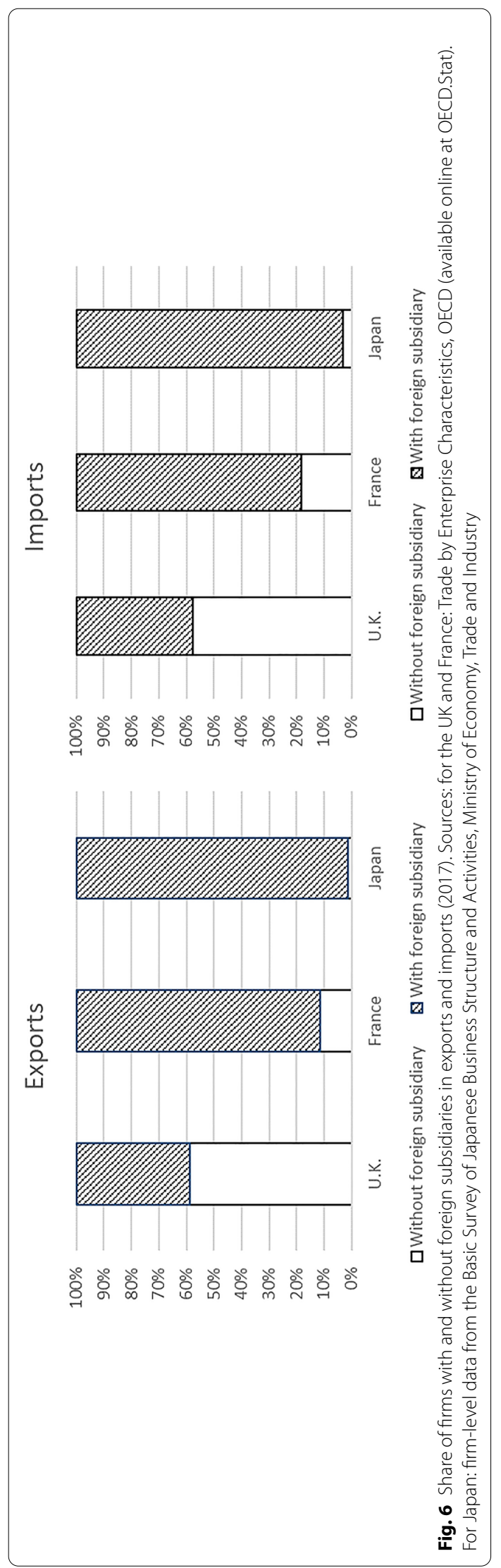




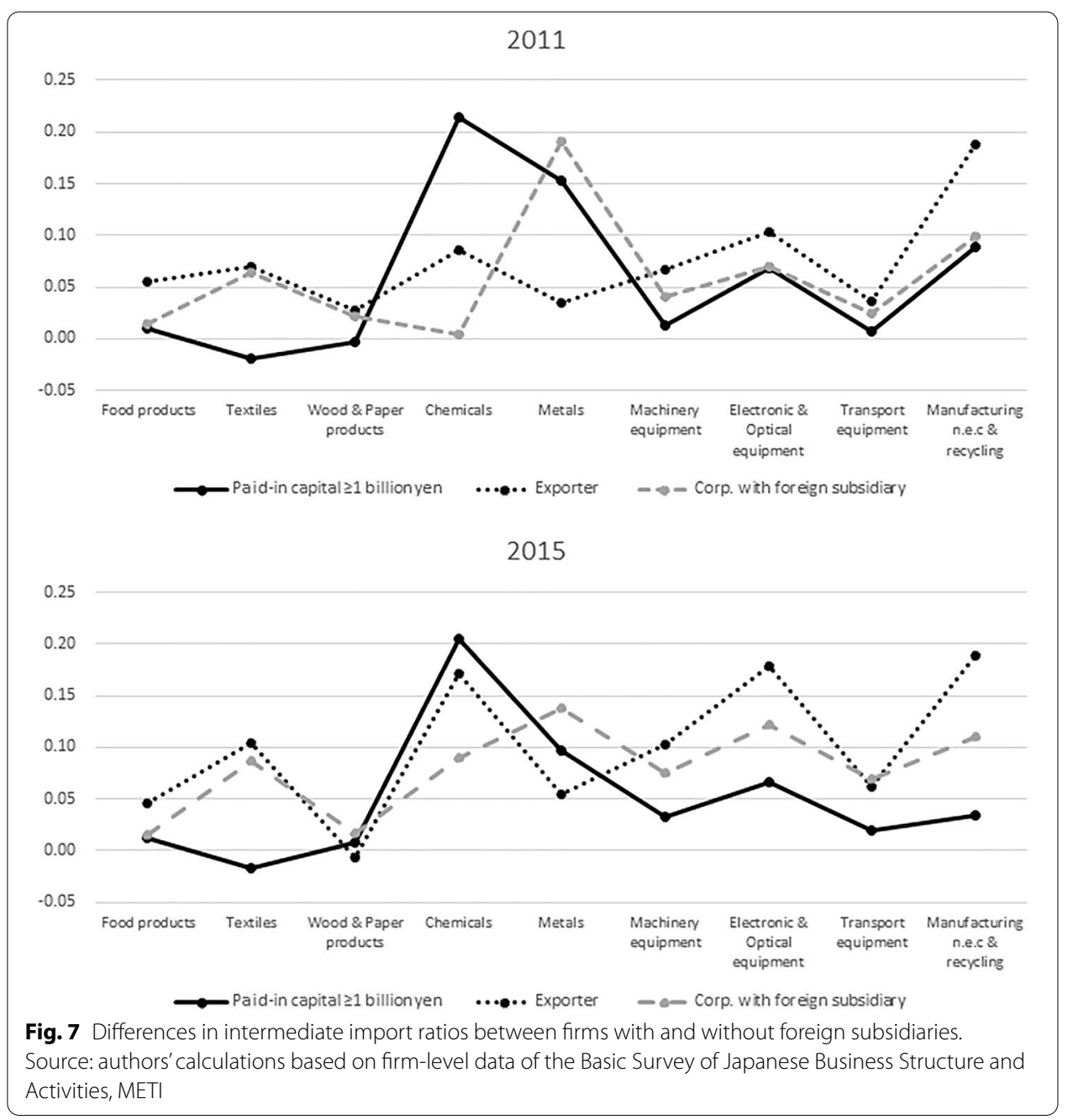

Table 5 Share in exports in 2015

\begin{tabular}{|c|c|c|c|c|c|c|c|c|c|}
\hline & $\begin{array}{l}\text { Food } \\
\text { (\%) }\end{array}$ & $\begin{array}{l}\text { Textiles } \\
\text { (\%) }\end{array}$ & $\begin{array}{l}\text { Paper } \\
\text { (\%) }\end{array}$ & $\begin{array}{l}\text { Chemicals } \\
\text { (\%) }\end{array}$ & $\begin{array}{l}\text { Metal } \\
(\%)\end{array}$ & $\begin{array}{l}\text { Machinery } \\
\text { (\%) }\end{array}$ & $\begin{array}{l}\text { Electronics } \\
\text { (\%) }\end{array}$ & $\begin{array}{l}\text { Transport } \\
\text { equipment } \\
\text { (\%) }\end{array}$ & $\begin{array}{l}\text { Other } \\
\text { manufacturing } \\
\text { (\%) }\end{array}$ \\
\hline $\begin{array}{l}\text { Export } \\
\text { share of } \\
\text { export- } \\
\text { ing firms }\end{array}$ & 100.0 & 100.0 & 100.0 & 100.0 & 100.0 & 100.0 & 100.0 & 100.0 & 100.0 \\
\hline $\begin{array}{l}\text { Export } \\
\text { share } \\
\text { of large } \\
\text { firms }\end{array}$ & & 94.3 & & 90.5 & & & & & \\
\hline $\begin{array}{l}\text { Export } \\
\text { share } \\
\text { of firms } \\
\text { with } \\
\text { foreign } \\
\text { subsidi- } \\
\text { aries }\end{array}$ & & 22.5 & 77.1 & & 63.2 & & & & \\
\hline
\end{tabular}


Table 6 Output shares in 2015

\begin{tabular}{|c|c|c|c|c|c|c|c|c|c|}
\hline & $\begin{array}{l}\text { Food } \\
(\%)\end{array}$ & $\begin{array}{l}\text { Textiles } \\
\text { (\%) }\end{array}$ & $\begin{array}{l}\text { Paper } \\
\text { (\%) }\end{array}$ & $\begin{array}{l}\text { Chemicals } \\
\text { (\%) }\end{array}$ & $\begin{array}{l}\text { Metal } \\
(\%)\end{array}$ & $\begin{array}{l}\text { Machinery } \\
\text { (\%) }\end{array}$ & $\begin{array}{l}\text { Electronics } \\
\text { (\%) }\end{array}$ & $\begin{array}{l}\text { Transport } \\
\text { equipment } \\
\text { (\%) }\end{array}$ & $\begin{array}{l}\text { Other } \\
\text { manufacturing } \\
(\%)\end{array}$ \\
\hline $\begin{array}{l}\text { Output } \\
\text { share of } \\
\text { export- } \\
\text { ing firms }\end{array}$ & 33.7 & 63.6 & 39.6 & 74.5 & 61.9 & 71.2 & 76.2 & 80.7 & 71.7 \\
\hline $\begin{array}{l}\text { Output } \\
\text { share } \\
\text { of large } \\
\text { firms }\end{array}$ & & 82.5 & & 80.2 & & & & & \\
\hline $\begin{array}{l}\text { Output } \\
\text { share } \\
\text { of firms } \\
\text { with } \\
\text { foreign } \\
\text { subsidi- } \\
\text { aries }\end{array}$ & & 29.4 & 29.1 & & 42.2 & & & & \\
\hline
\end{tabular}

for the paper and metal industries. For the textile industry, the output weight of firms with foreign subsidiaries is relatively small (bold text in Table 6), justifying the use of exporting and non-exporting as the heterogeneity consideration for the textile industry.

Table 6 is the extended import table incorporating the differences in intermediate import ratios (only manufacturing industries are shown). Based on Hagino's (2017) analysis demonstrating that differences in industries' intermediate import ratios are mainly due to the import of goods that an industry needs to produce, such differences are assumed to derive from differences in within-industry imports. For example, exporting automobile firms in the transport equipment industry import a large number of automobile parts, whereas non-exporting automobile firms mainly procure such parts from domestic firms. As a result, the transport equipment industry's difference in import intermediate ratio becomes largest in the import of transport equipment. Such a result is assumed to be reasonable, and therefore, reflect differences in intermediate import ratios in the diagonal cells (bold text in Table 7).

\subsection{Usefulness of the EIOT}

Table 8 presents the VS coefficients for the non-extended IOT and Table 9 those for the EIOT.

Table 10 reveals the VS indicator based on the EIOT (34.3\%) is 70\% larger than that based on the non-extended IOT (20.5\%). This implies that the extension of IOTs incorporating differences in intermediate import ratios makes it possible to more comprehensively capture VS, and potentially, foreign value added.

OECD TiVA indicators show that Japan's foreign value added included in exports is about $15 \%$. Despite the similarity of the underlying concept of the VS indicator and foreign value added, the former is $30 \%$ larger than the latter. This gap may be caused by the fact that the VS indicator calculated in this research is based on one country's IOT and does not exclude the domestic value added included in imported intermediate goods (APEC 2019, De Becker and Yamano 2012), which is not negligible in machinery industries. If the domestic value added included in imported intermediate goods is deducted 


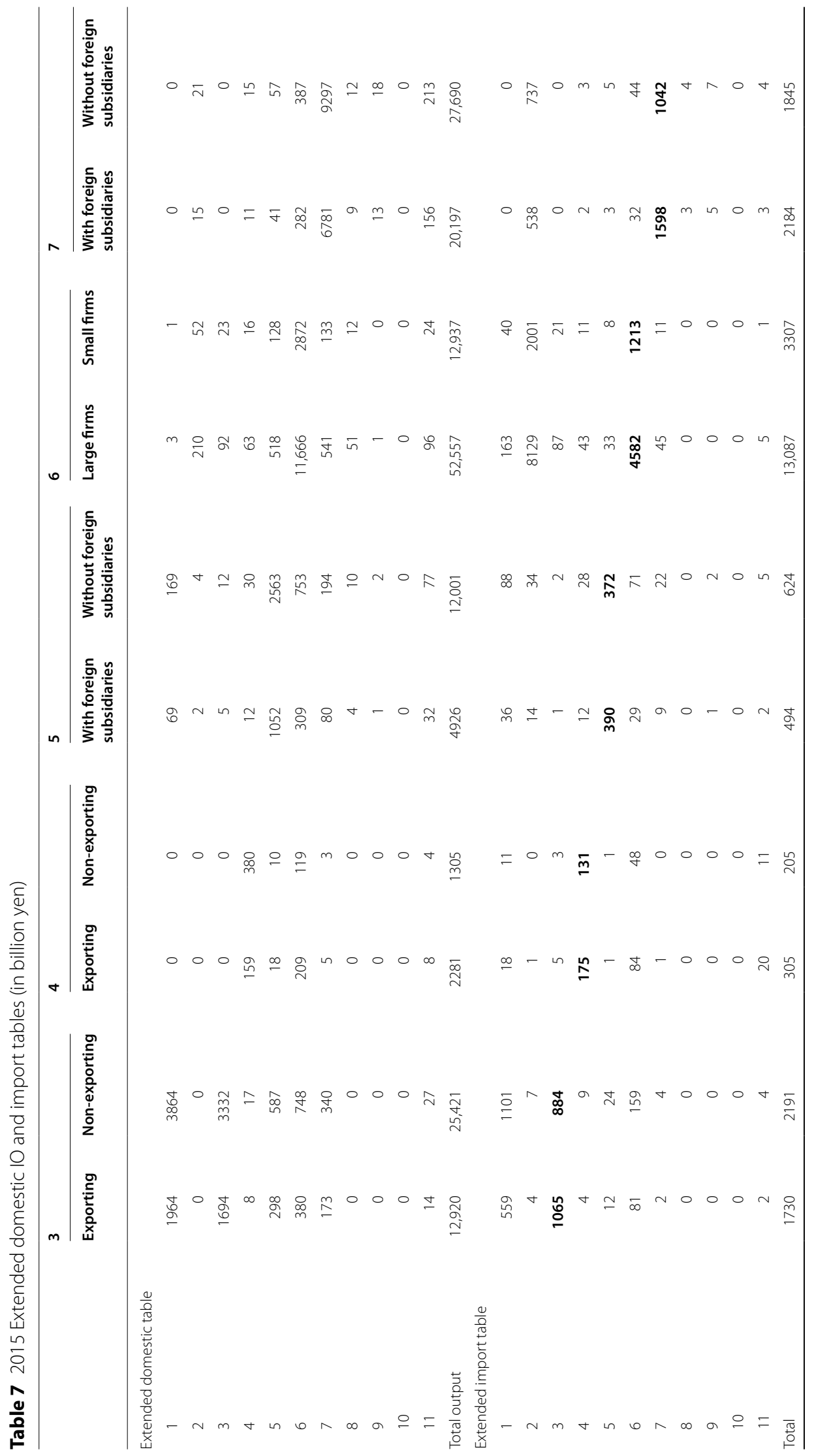




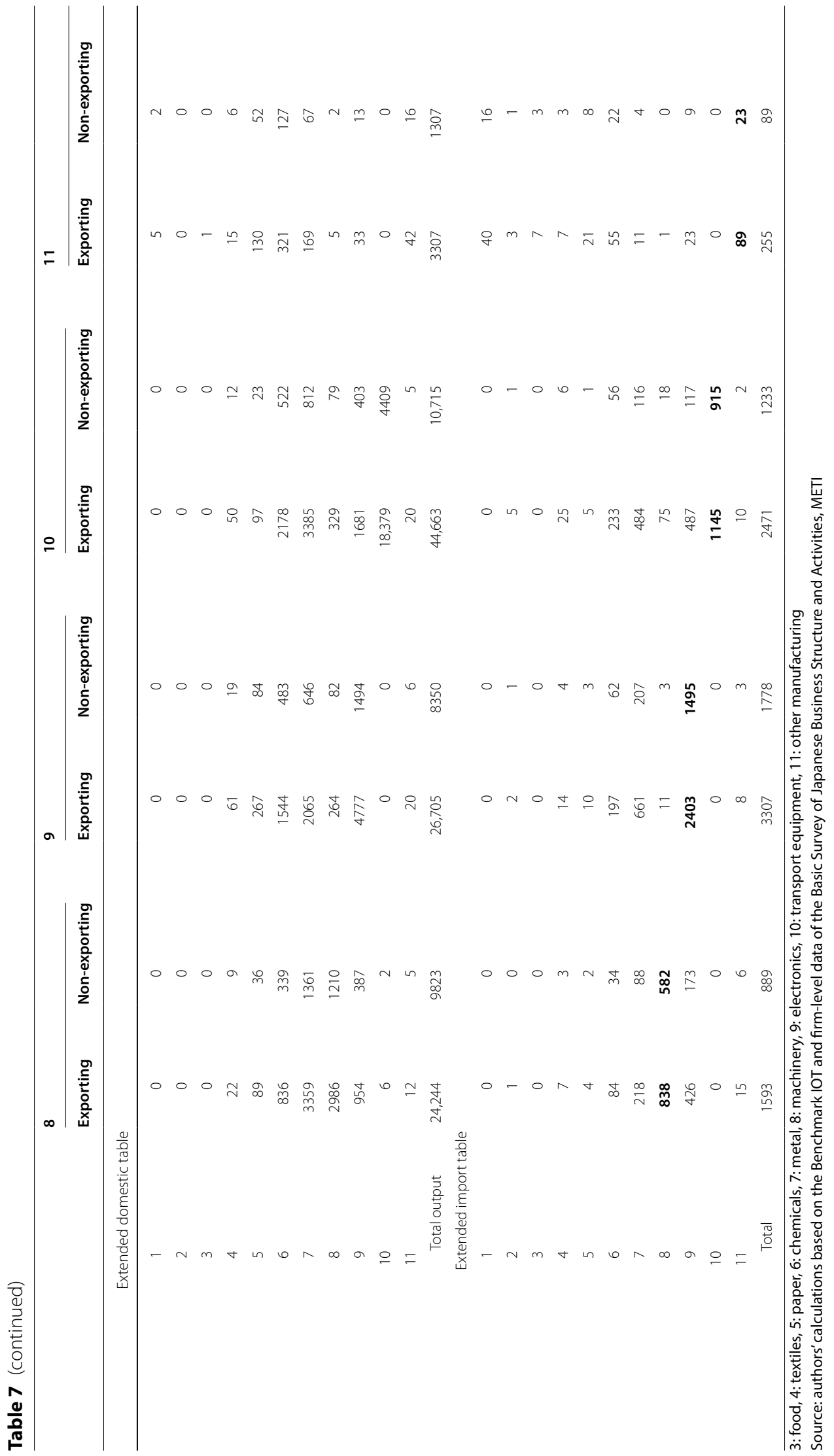




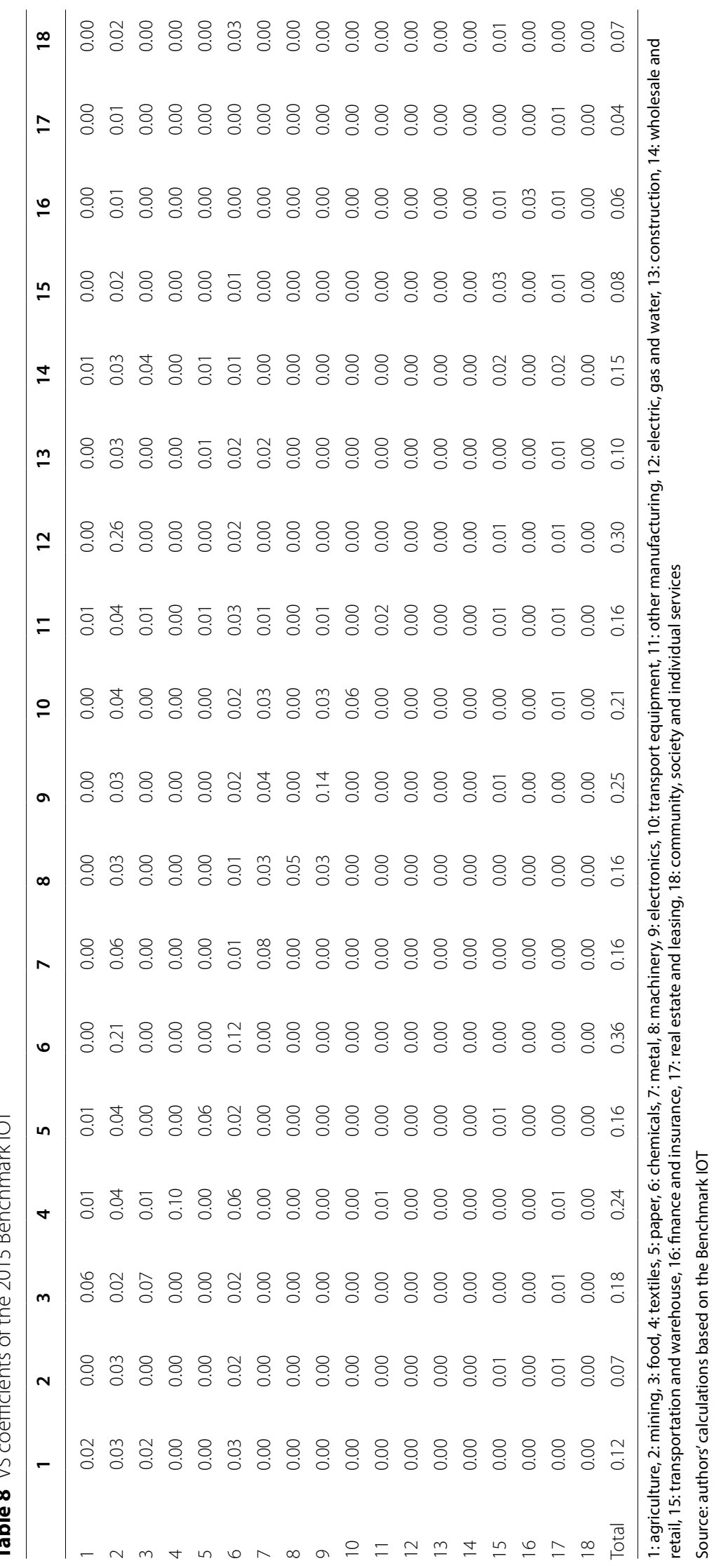


Table 9 VS coefficients of the 2015 extended IOT

\begin{tabular}{|c|c|c|c|c|c|c|c|c|c|c|c|c|c|c|}
\hline & 2 & 2 & $3-1$ & $3-2$ & 4-1 & 4-2 & $5-1$ & $5-2$ & 6-1 & $6-$ & & $7-1$ & $7-2$ & $3-1$ \\
\hline & 0. & 0.00 & 0. & & & & 0.01 & 0 & 0 & & & 0.00 & & 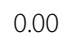 \\
\hline 2 & 0. & 0.03 & & & & & & & & & & & & .02 \\
\hline-1 & 0.01 & 0.00 & 0.05 & & 01 & 00 & 0.00 & & 0.00 & & & 0.00 & .00 & 0.00 \\
\hline-2 & 0.01 & 0.00 & 0.04 & & .00 & 0.00 & .00 & 00 & 0.00 & 0.0 & & 0.00 & .00 & 0.00 \\
\hline & 00 & 0.00 & 0.00 & & 10 & & & & 0.00 & & & & 0 & .00 \\
\hline $4-2$ & 00 & 0.00 & 0. & & 8 & & & & & & & & & 00 \\
\hline & 0.00 & 0.00 & 0.00 & & & & & & & & & & & .00 \\
\hline 2 & 0.00 & 0.00 & 0.00 & 0 & 0.00 & 0.00 & 0.05 & 0.0 & 0.00 & 0. & & 0.00 & .00 & 0.00 \\
\hline-1 & 0.02 & 0.01 & 0.01 & 0.01 & 0.08 & 0.02 & 0.01 & 0.01 & 0.09 & 0. & & 0.00 & .00 & 0.01 \\
\hline $5-2$ & 0.01 & 0.01 & 0.01 & 0.01 & & & & & & & & & 0 & .00 \\
\hline & 0.00 & 0.00 & 0.00 & & 0 & & & & & & & & & 02 \\
\hline & 0.00 & 0.00 & & & & & & & & & & & & .01 \\
\hline & 0.00 & 0.00 & & & & & & $c$ & & 0. & & & & .02 \\
\hline $8-2$ & 0.00 & 0.00 & 0 & 0 & 0 & 0 & .00 & 0 & 0.00 & 0.0 & & & & .02 \\
\hline 9 & 0.00 & 0.00 & & 0 & 0 & & & & 0.00 & D. & & & & 02 \\
\hline g. & 0.00 & 0.00 & 0.00 & $0 . c$ & 0. & & & 0.00 & 0.00 & 0. & & 0 & U & .01 \\
\hline Tot & 0.00 & 0.00 & 0.00 & 0 & 0.00 & & & 0.00 & 0.00 & 0.6 & & 00 & 0.00 & .00 \\
\hline & 0.00 & 0.0 & & & & & & & & 0. & & & & 00 \\
\hline $11-1$ & 0.00 & 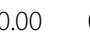 & & & & & & 0.00 & 0 & 0.0 & & & & 00 \\
\hline $11-2$ & 0.00 & 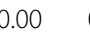 & 0 & c & & & & & & 0.6 & & & & 00 \\
\hline 12 & 0.01 & 0.00 & 0. & 0 & 0. & & & 0. & 0.04 & 0. & & 5 & & .02 \\
\hline 13 & 0.00 & 0.00 & 0. & 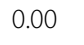 & 0. & & & 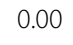 & 0 & 0.0 & & 00 & 0.00 & .00 \\
\hline 14 & 0.02 & 0.01 & & & & & & & 0 & 0.0 & & 05 & & .06 \\
\hline & 0.02 & 0.0 & 0. & & & & & 7 & 5 & 0.0 & & & & 05 \\
\hline & 0.00 & 0.00 & 0. & 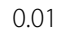 & 0 & 0 & & . & 0 & 0.0 & & 01 & 01 & 01 \\
\hline 1 & 0.01 & 0.01 & 0. & 0 & & & & 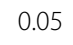 & 0.05 & 0.0 & & 0.03 & 0.03 & 0.05 \\
\hline $1 \varepsilon$ & 0.00 & 0.00 & 0.00 & 0.00 & 0.00 & & 0.00 & 0.00 & 0.00 & 0.0 & & 0.00 & 0.00 & 0.00 \\
\hline \multirow[t]{2}{*}{ Tot } & 0.17 & 0.10 & 0.43 & 0.38 & 0.96 & 0.41 & 0.47 & 0.42 & 0.54 & 0.5 & & 0.35 & 0.31 & 0.34 \\
\hline & 8-2 & $9-1$ & $9-2$ & $10-1$ & $10-2$ & $11-1$ & $11-2$ & 12 & 13 & 14 & 15 & 16 & 17 & 18 \\
\hline 1 & & 0.00 & 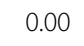 & & & & & & & & 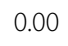 & 0.00 & & 0 \\
\hline 2 & & & & & & & & & 2 & & & & & \\
\hline $3-1$ & 0.00 & 0.00 & 0.00 & 0.00 & 0.00 & 0.00 & & 0.00 & 0.00 & 0.01 & 0.00 & 0.00 & 0.00 & 0.00 \\
\hline $3-2$ & 0.00 & 0.00 & 0.00 & 0.00 & 0.00 & 0.00 & 0.00 & 0.00 & 0.00 & 0.01 & 0.00 & 0.00 & 0.00 & 0.00 \\
\hline $4-1$ & 0.00 & 0.00 & 0.00 & 0.00 & 0.0 & 0.0 & 008 & 0.00 & 0.00 & 0.00 & 0.00 & 0.00 & 0.00 & 0.00 \\
\hline $4-2$ & 0 & 0.00 & 0.00 & 0 & & & & 0 & 0.00 & 0.00 & 0.00 & 0.00 & 0 & .00 \\
\hline $5-$ & & & & & & & & & & & & & & .00 \\
\hline $5-2$ & & 0.00 & 0.00 & 0.00 & & & & & & 0.00 & & & & 0.00 \\
\hline $6-1$ & 0.01 & 0.02 & 0.02 & 0.02 & 0.02 & 0.02 & 0.02 & 0.01 & 0.01 & 0.00 & 0.01 & 0.00 & 0.00 & 0.02 \\
\hline $6-2$ & 0.00 & 0.01 & 0.01 & 0.01 & 0.01 & 0.01 & 0.01 & 0.01 & 0.00 & 0.00 & 0.01 & 0.00 & 0.00 & 0.01 \\
\hline $7-1$ & 0.02 & 0.03 & 0.03 & 0.02 & 0.02 & 0.01 & 0.01 & 0.00 & 0.01 & 0.00 & 0.00 & 0.00 & 0.00 & 0.00 \\
\hline $7-2$ & 0.01 & 0.01 & 0.01 & 0.01 & 0.0 & 0.00 & 0.0 & 0.00 & 0.00 & 0.00 & 0. & 0.00 & 0.00 & 0.00 \\
\hline $8-1$ & 0.04 & 0.00 & 0.00 & 0.00 & 0.00 & & & & & & & 0.00 & 0.00 & 0.00 \\
\hline $8-2$ & 0.03 & 0.00 & 0.00 & 0.00 & 0.00 & & & & 0.00 & 0.00 & 0.00 & 0.00 & 0.00 & 0.00 \\
\hline $9-1$ & 0.02 & 0.07 & 0.13 & 0.02 & 0.02 & 0.01 & 0.01 & 0.00 & 0.00 & 0.00 & 0.00 & 0.00 & 0.00 & 0.00 \\
\hline $9-2$ & 0.01 & 0.04 & 0.08 & 0.01 & 0.01 & 0.00 & 0.00 & 0.00 & 0.00 & 0.00 & 0.00 & 0.00 & 0.00 & 0.00 \\
\hline 10-1 & 0.00 & 0.00 & 0.00 & 0.03 & 0.06 & 0.00 & 0.00 & 0.00 & 0.00 & 0.00 & 0.00 & 0.00 & 0.00 & 0.00 \\
\hline $10-2$ & 0.00 & 0.00 & 0.00 & 0.02 & 0.05 & 0.00 & 0.00 & 0.00 & 0.00 & 0.00 & 0.00 & 0.00 & 0.00 & 0.00 \\
\hline $11-1$ & 0.00 & 0.00 & 0.00 & 0.00 & 0.00 & 0.02 & 0.01 & 0.00 & 0.00 & 0.00 & 0.00 & 0.00 & 0.00 & 0.00 \\
\hline & 0.00 & 0.00 & .00 & & & & 0.00 & 0.00 & 0.00 & 0.00 & 0.00 & 0.00 & 0.00 & 0.00 \\
\hline
\end{tabular}


Table 9 (continued)

\begin{tabular}{ccccccccccccccc}
\hline & $\mathbf{8 - 2}$ & $\mathbf{9 - 1}$ & $\mathbf{9 - 2}$ & $\mathbf{1 0 - 1}$ & $\mathbf{1 0 - 2}$ & $\mathbf{1 1 - 1}$ & $\mathbf{1 1 - 2}$ & $\mathbf{1 2}$ & $\mathbf{1 3}$ & $\mathbf{1 4}$ & $\mathbf{1 5}$ & $\mathbf{1 6}$ & $\mathbf{1 7}$ & $\mathbf{1 8}$ \\
\hline 12 & 0.02 & 0.03 & 0.03 & 0.03 & 0.03 & 0.02 & 0.02 & 0.00 & 0.01 & 0.00 & 0.00 & 0.00 & 0.00 & 0.00 \\
13 & 0.00 & 0.00 & 0.00 & 0.00 & 0.00 & 0.00 & 0.00 & 0.00 & 0.00 & 0.00 & 0.00 & 0.00 & 0.00 & 0.00 \\
14 & 0.06 & 0.07 & 0.07 & 0.08 & 0.08 & 0.08 & 0.08 & 0.00 & 0.01 & 0.01 & 0.01 & 0.00 & 0.00 & 0.01 \\
15 & 0.05 & 0.05 & 0.05 & 0.05 & 0.05 & 0.19 & 0.19 & 0.01 & 0.01 & 0.01 & 0.04 & 0.01 & 0.01 & 0.01 \\
16 & 0.01 & 0.01 & 0.01 & 0.01 & 0.01 & 0.02 & 0.02 & 0.00 & 0.00 & 0.00 & 0.00 & 0.03 & 0.00 & 0.00 \\
17 & 0.05 & 0.06 & 0.06 & 0.06 & 0.06 & 0.05 & 0.05 & 0.01 & 0.01 & 0.01 & 0.01 & 0.01 & 0.01 & 0.01 \\
18 & 0.00 & 0.00 & 0.00 & 0.00 & 0.00 & 0.00 & 0.00 & 0.00 & 0.00 & 0.00 & 0.00 & 0.00 & 0.00 & 0.00 \\
Total & 0.36 & 0.43 & 0.52 & 0.42 & 0.48 & 0.52 & 0.51 & 0.31 & 0.08 & 0.09 & 0.12 & 0.08 & 0.05 & 0.09 \\
\hline
\end{tabular}

1: agriculture, 2: mining, 3: food, 4: textiles, 5: paper, 6: chemicals, 7: metal, 8: machinery, 9: electronics, 10: transport equipment, 11: other manufacturing, 12: electric, gas and water, 13: construction, 14: wholesale and retail, 15: transportation and warehouse, 16: finance and insurance, 17: real estate and leasing, 18: community, society and individual services

For industries 3-11, the subnumbers (e.g., 3-1 and 3-2) denote elements of the extension

Source: authors' calculations based on the Benchmark IOT and firm-level data of the Basic Survey of Japanese Business Structure and Activities, METI

using corresponding data from the OECD TiVA indicators, the VS indicator is reduced slightly to $20.1 \%$. To calculate the foreign value added included in imported intermediate goods in this way, data from Japan's trade partners must be considered and made endogenous in the analysis, which requires an international EIOT.

\section{Conclusion}

This paper discussed the various aspects of firm heterogeneity that should be incorporated into Japan's EIOT. Based on the analysis using firm-level data, it was concluded that processing and assembly industries, such as the machinery, electronics, transport equipment industries, food, and textile industries, heterogeneity between exporters and non-exporters should be incorporated. For the chemical industry, heterogeneity between small and large firms should be incorporated, while for paper and metal industries, heterogeneity between firms with and without foreign subsidiaries should be incorporated. Based on these results, an EIOT was constructed for Japan. To examine the usefulness of this table, Japan's VS indicator was estimated, finding the VS indicator based on the EIOT to be $70 \%$ larger than that based on the non-extended IOT. This implies that the foreign value added could be more comprehensively captured by the extension of an IOT. For more precise calculation of the foreign value added, however, Japan's EIOT should be incorporated into an international IOT. For this purpose, we would like to work with the OECD. Doing so may enable verification of the reliability of the input structure method proposed in this study.

A future research challenge is the construction of an EIOT incorporating different elements of heterogeneity. Specifically, capturing the impact of firms' globalization on the SNA, identifying multinational corporations could be useful. For this purpose, the OECD has proposed to incorporate the distinction between domestically owned firms without foreign subsidiaries, domestically owned firms with foreign subsidiaries, and foreign-owned firms in the EIOT. Following this proposal will present an opportunity to extend the work in this paper and present a potential research task for next research stage. 


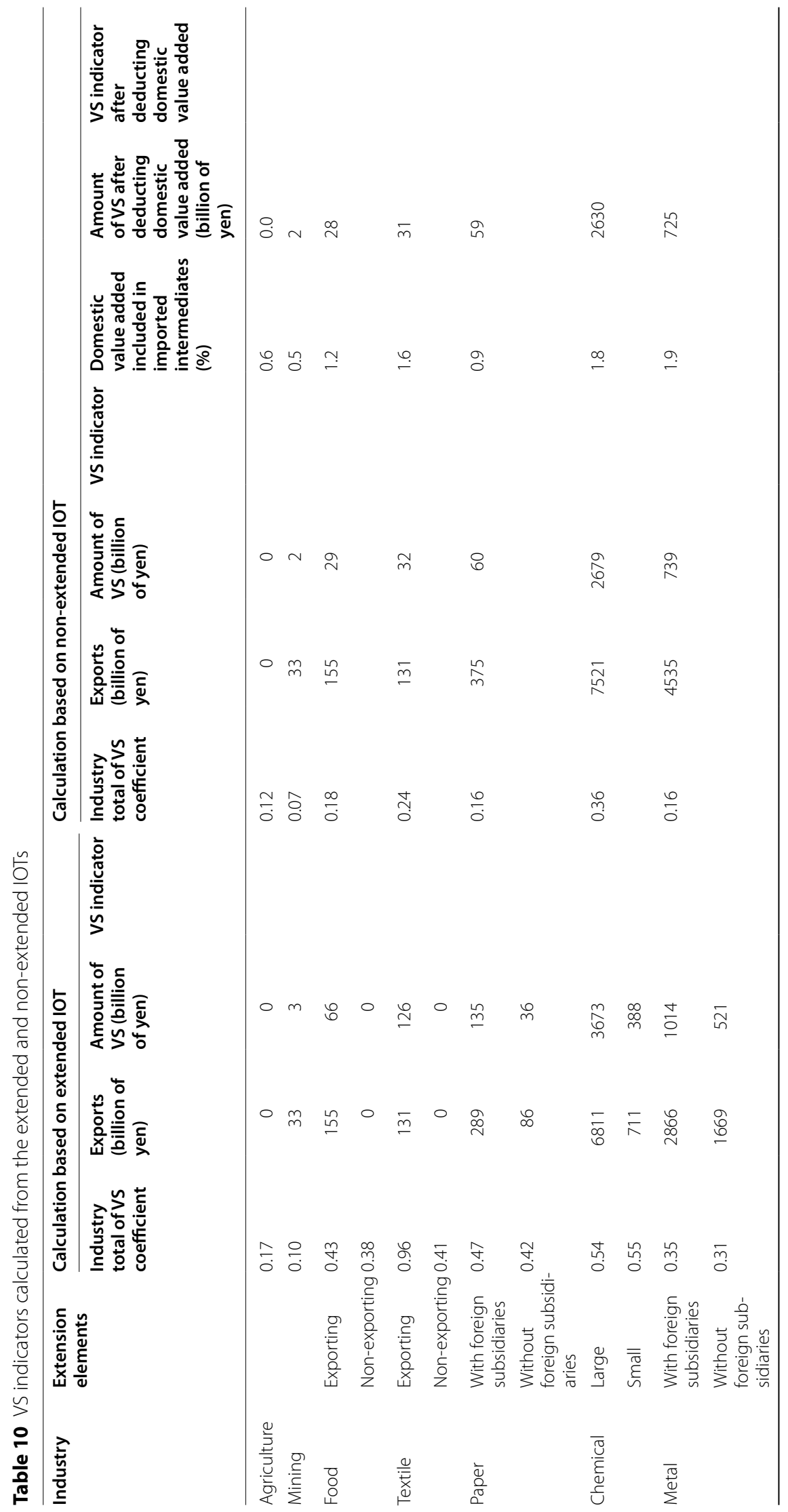




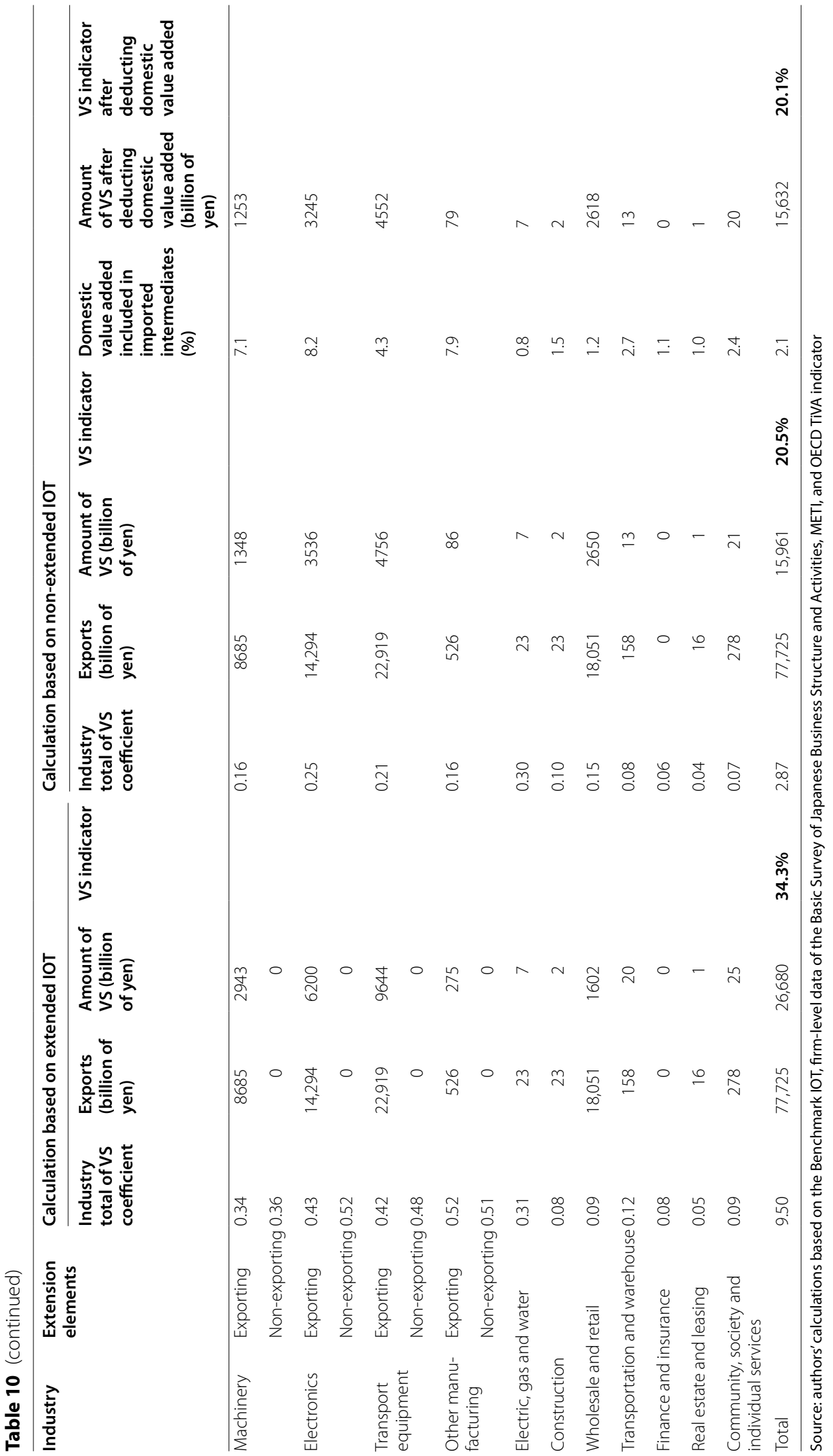




\section{Abbreviations}

BSBSA: Basic Survey of Japanese Business Structure and Activities; EIOT: Extended input-output table; FSSCl: Financial Statement Statistics of Corporations by Industry; METI: Japan's Ministry of Economy, Trade and Industry; OECD: Organisation for Economic Co-operation and Development; TiVA: Trade in value added; VS: Vertical specialization.

\section{Acknowledgements}

Not applicable.

\section{Authors' contributions}

SH designed the work and Kim made calculations. SH interpreted the results and made the first draft. JK revised the manuscript. Both authors read and approved the final manuscript.

\section{Funding}

Not applicable.

\section{Availability of data and materials}

The Japanese benchmark input-output table used in this study is available on the website of the Ministry of Internal Affairs and Communication of Japan. Firm-level data of the Basic Survey of Japanese Business Structure and Activities are available through requests to the Ministry of Economy and Industry of Japan.

\section{Declarations}

Ethics approval and consent to participate

Not applicable.

\section{Consent for publication}

Not applicable.

\section{Competing interests}

The authors declare that they have no competing interests.

\section{Author details}

${ }^{1}$ Senior Research Fellow, Economic and Social Research Institute, Cabinet Office (ESRI), 1-6-1 Nagata-cho, Chiyoda-ku, Tokyo 100-8914, Japan. ${ }^{2}$ Graduate School of Humanities and Social Sciences, Okayama University, 3-1-1 Tsushima-naka, Kita-ku, Okayama 700-8530, Japan.

Received: 3 August 2021 Revised: 11 November 2021 Accepted: 14 November 2021

Published online: 04 December 2021

\section{References}

APEC Committee on Trade and Investment, 2019. Methodologies of Constructing the APEC TiVA Database for Better Understanding Global Value Chains in the APEC Region.

De Becker K, Yamano N (2012) 'International Comparative Evidence on Global Value Chains, OECD Science', Technology and Industry Working Papers 2012/03.

Hagino S (2017) Identifying Firm Heterogeneity in Japan by Developing TEC and TEC Plus Data. Fukuyama University Journal of Economics

Hummels D, Ishii J, Yi K-M (2001) The nature and growth of vertical specialization in world trade. Journal of International Economics 54:75-96

Ito K, Deseatnicov I, Fukao K (2017) 'Japanese Plants' heterogeneity in sales, factor inputs, and participation in global value chains. RIETI Discussion Paper Series, 17-E-117

Johnson RC, Noguera G (2012) Accounting for intermediates: production sharing and trade in value added. Journal of International Economics 86(2):224-236

OECD Expert Group on Extended Supply-Use Tables (2014a) Draft:Terms of Reference

OECD (2014b) Extending OECD's Work on Measuring Trade in Value-Added, STD/CSSP(2014)7

OECD (2015) Firm Heterogeneity and Trade in Value-Added, STD/CSSP/WPTGS(2015)23

OECD (2018) Addressing the Challenges of Globalisation in National Accounts, COM/SDD/DAF(2018)6

\section{Publisher's Note}

Springer Nature remains neutral with regard to jurisdictional claims in published maps and institutional affiliations. 